\title{
Genetic Variation of Amaranthus Retroflexus L. and Chenopodium Album L. Suggests Multiple Independent Introductions
}

\section{Shiva Hamidzadeh Moghadam}

University of Mohaghegh Ardabili

Mohammad Taghi Alebrahim ( $\Delta$ m_ebrahim@uma.ac.ir)

University of Mohaghegh Ardabili

Mehdi Mohebodini

University of Mohaghegh Ardabili

Dana R. MacGregor

Rothamsted Research

Te-Ming Tseng

Mississippi State University

\section{Research Article}

Keywords: invasive plants, severe ecological, UPGMA, ISSR

Posted Date: April 15th, 2021

DOl: https://doi.org/10.21203/rs.3.rs-415316/v1

License: (9) This work is licensed under a Creative Commons Attribution 4.0 International License.

Read Full License 


\section{Genetic variation of Amaranthus retroflexus L. and Chenopodium album L.} suggests multiple independent introductions

3 Shiva Hamidzadeh Moghadam ${ }^{1}$, Mohammad Taghi Alebrahim ${ }^{*}$, Mehdi Mohebodini², Dana

4 R. MacGregor ${ }^{3}$ and Te-Ming Tseng ${ }^{4}$

$5{ }^{1}$ Department of Agronomy and Plant Breeding, University of Mohaghegh Ardabili, Ardabil, Iran

$6 \quad{ }^{2}$ Department of Horticultural Sciences, University of Mohaghegh Ardabili, Ardabil, Iran

$7 \quad{ }^{3}$ Department of Biointeractions and Crop Protection, Rothamsted Research, Harpenden, United

8 Kingdom

$9{ }^{4}$ Department of Plant and Soil Sciences, Mississippi State University, Starkville, MS, United

10 States

11 Corresponding author :m_ebrahim@uma.ac.ir

12 Abstract

13 Amaranthus retroflexus L. and Chenopodium album L. are invasive plants that globally cause

14 severe ecological and economic damage. In this study, we collected DNA from populations of

15 these highly successful invaders from three countries and assessed genetic diversity using inter-

16 simple sequence repeat (ISSR) markers. Both weed species showed low genetic diversity within a

17 population and high genetic diversity among populations $(\mathrm{GST}=0.82)$, and the value of gene flow

18 among the populations was low $(\mathrm{Nm}=0.1)$. Both UPGMA clustering and principal coordinate

19 analysis indicated the existence of four distinct groups for A. retroflexus L. and C. album L.,

20 however these groups do not correlate with geographic origin. The high levels of genetic diversity

21 observed among populations indicates that each population was individually introduced, probably

22 through human activity. This knowledge helps to guide weed management and control strategies

23 for field populations of these two prominent invasive weeds as it demonstrates each population

24 must be considered separately and suggests they are armed with a considerable variety of genetic

25 traits that could be used to avoid management practices. 


\section{Introduction}

28 Bioinvasions are one of the biggest threats to biodiversity, ecosystem integrity, agriculture,

29 fisheries and epidemiology ${ }^{1}$. Despite the fact that the rapid spread of exotics has received 30 appreciable attention within the international community and has galvanized vital ecological 31 research ${ }^{2,3}$, there still is a lack of understanding about what is necessary to drive a successful 32 invasion. Redroot pigweed (Amaranthus retroflexus L.) and lamb's quarters (Chenopodium album 33 L.) are fast-growing and highly competitive weedy annual plants in the family of Amaranthaceae.

34 Both exhibit significant morphological and biochemical diversity ${ }^{4}$ and cause large yield losses 35 throughout the world's agricultural areas 5,6. In many parts of the world, A. retroflexus is 36 considered among the most troublesome weeds ${ }^{7}$ due largely to its high fecundity ${ }^{8}$ and long lived 37 seeds ${ }^{9}$, which together allow it to maintain a constant soil seed bank. A. retroflexus negatively 38 influences row crops, such as sugar beet ${ }^{10}$, soybean ${ }^{11}$, potato ${ }^{12,13}$, cotton $^{14}$ and corn $^{15}$. C. album is 39 a pest of 40 crops in 47 countries $^{6}$. These crops include wheat, barley, mustard, and gram ${ }^{16,17,18}$. 40 Like A. retroflexus, C. album's success is driven by vigorous and highly adapted reproduction.

41 Each C. album plant produces thousands to tens of thousands of seeds ${ }^{6}$ which remain viable for up 42 to 4 decades $^{19}$. C. album seeds exhibit considerable physical and biochemical polymorphisms ${ }^{20}$, 43 which alter seed dormancy and germination requirements and therefore allow plants to germinate 44 under a range of environmental conditions ${ }^{21}$. These two weeds are highly successful bioinvaders 45 and are therefore good systems to use to investigate the genetic fingerprints of effective bioinvasions.

Evolutionary genetics are a valuable tool for revealing traits that drive bioinvasion success ${ }^{1}$. Genetic and evolutionary processes are the principal determinant of an invasive species' ability to establish and spread ${ }^{22,23}$ ). Factors influencing a plant's potential to rapidly and efficiently colonize new habitats include: wide environmental tolerance, phenotypic flexibility, inbreeding coefficient or any form of asexual reproduction, efficient dispersal abilities, high relative growth rate, and high ability to compete ${ }^{24}$. Colonization of new habitats is usually reflected in a "founder effect" and subsequent genetic drift decreases the variation among the population promoting differentiation between it and other populations ${ }^{25}$. Compared to native species, alien species commonly display different genetic variation, population structure and phenotypic characteristics in response to the selective pressures of demographic transition, which may reflect earlier 
57 evolutionary histories as well as stochastic and selection process ${ }^{26}$. Bioinvasion events also provide 58 useful opportunities for analysis of contemporary evolution ${ }^{27}$.

59 Molecular markers are important tools for the analysis of genetic diversity and 60 characterization of plant genotypes as they are highly reproducible and accurate. Commonly used 61 by plant breeders, molecular phylogenetic studies discriminate among genotypes by determining 62 the extent of variation within and between species $^{28}$. In the last decade, inter simple sequence 63 repeat (ISSR) markers have been successfully utilized for diversity studies and structuring of 64 natural populations ${ }^{29}$. ISSR markers generate highly reproducible banding patterns from a single 65 polymerase chain reaction (PCR) amplification, making them the most commonly used markers 66 in intra-specific diversity analysis ${ }^{30,31}$.

67 Despite the severe ecological and economic damage caused by invasive species when they successfully colonize new areas, the factors that allow invaders to become successful are not well defined. Understanding how genetic diversity correlates with distribution offers insights into the mechanisms of invasion(s). The objective of this study was to characterize the genetic diversity of Iranian compared to French and Spanish A. retroflexus L. and C. album L. populations using ISSR markers to investigate the genetic variation of these weeds. Despite being autogamous, C. album is the most polymorphic species of the genus Chenopodium; previous studies explored this taxonomic complexity through cytology ${ }^{32}$, karyotypic analysis ${ }^{33}$, flavonoid profiling ${ }^{34}$, random amplified polymorphic DNA (RAPD) profiles $^{34}$ and ISSR marker analysis ${ }^{35}$. Conversely $A$. retroflexus is partly autogamous, but a study of the genetic structure of A. retroflexus in Central

77 Europe using isoenzyme analysis showed moderate levels of genetic diversity and strong evidence 78 for inbreeding within populations compared to other herbaceous plants ${ }^{36}$. Therefore, there is a 79 precedence for using A. retroflexus and C. album for evolutionary genetic studies. The Iranian 80 populations investigated here show very diverse morphological and biochemical traits $\left({ }^{37,38,4}\right)$. We 81 also included a smaller number of French and Spanish populations in our analysis to assess the 82 effect of distance on genetic variation as it was extremely unlikely that genetic exchange between 83 these and the Iranian populations would have occurred. Our results show similar genetic variations 84 regardless of the distances between populations and groupings that mingled the French and 85 Spanish populations with the Iranian ones. Our data indicates a high degree of variation among a 86 species which suggests population isolation and multiple introduction events have occurred. 
Materials and Methods

\section{Plant Materials}

89 The collection and cultivation of these materials are described elsewhere ${ }^{4}$ that comply with

90 relevant institutional guidelines and legislation. In brief, seeds were collected from $16 \mathrm{~A}$.

91 retroflexus and 17 C. album naturally distributed populations in different provinces of Iran, Spain

92 and France during 2016-2017 by Research Institute of Forests and Rangelands (RIFR). Each

93 population collection point was positioned by GPS, with the location details listed in Table 1.

94 These seeds were cultivated at distance of $20 \mathrm{~cm}$ in row and $30 \mathrm{~cm}$ between rows at the

95 experimental field of the agriculture research of University of Mohaghegh Ardabili $\left(38.19^{\circ} \mathrm{N}\right.$,

$9648.20^{\circ} \mathrm{E}$ ) during the summer of 2018. Young leaf tissues were collected from individual plants and

97 then stored in an $-80^{\circ} \mathrm{C}$ freezer until required.

98

99

100

101

102

103

104

105

106

107

108

109

110

\section{Data Analysis}

11213 of the 52 primers tested clearly and reproducibly amplified ISSR fragments. These were scored 113 based on a binary matrix for presence (1) or absence (0) of bands. Discriminatory power of the 114 primers was evaluated by means of resolving power (Rp), mass resolving power (MRP), 
115 polymorphic information content (PIC), marker index (MI). Rp of each primer which is the ability 116 of each primer to detect level of variation between individuals was calculated according to (Prevost 117 and Wilkinson ${ }^{40}$

$$
\mathrm{Rp}=\sum \mathrm{bI}
$$

119 where bI (band informativeness) takes the values of: $1-[2|0.5-\mathrm{p}|]$, where $\mathrm{p}$ is the proportion of 120 individuals containing the band. Further, mean resolving power (MRP) for each primer was 121 calculated via

$$
\mathrm{MRP}=\frac{1}{\mathrm{n}} \sum \mathrm{bI}
$$

123 following Milbourne et $\mathrm{al}^{41}$. PIC value was calculated according to Roldán-Ruiz et $\mathrm{al}^{42}$ :

$$
\mathrm{PIC}=2 \mathrm{fi}(1-\mathrm{fi})
$$

125 where fi is the frequency of fragments present in that locus and (1-fi) is the frequency of the null 126 allele. MI, a measure of overall utility of a molecular marker technique, for each primer was 127 calculated as a product of two functions, the polymorphic information content and effective 128 multiplex ratio $(\mathrm{EMR})^{41}$ i.e.,

$$
\mathrm{MI}=\mathrm{PIC} \times \mathrm{EMR}
$$

130 The effective multiple ratio $(E M R=n p \beta)$ is the product of the number of polymorphic loci (np) 131 in the population analyzed and the fraction of markers that were polymorphic $(\beta)^{43}$.

The resulting binary data matrix was analyzed using POPGENE version $1.32^{44}$ to examine 133 different genetic diversity parameters including number of polymorphic loci (PL), percentage of 134 polymorphic loci (PPL), Observed number of alleles (Na), Effective number of alleles (Ne), Nei's 135 gene diversity $(\mathrm{H})$, Shannon's information index (I), gene flow based on McDermott and 136 McDonald $^{45}$ :

$$
\mathrm{Nm}=0.5(1-\mathrm{GST}) / \mathrm{GST}
$$

To examine the genetic relationship among populations, unbiased genetic distance and genetic identity ${ }^{46}$ were also calculated by POPGENE and a dendrogram was constructed from

140 Nei's genetic distance with the unweighted pair-group method of averages (UPGMA) using 141 NTSYSpc 1.02 software $^{47}$. To determine the quality of clustering ${ }^{48}$, UPGMA cluster analysis was 142 used to measure cophentic correlation coefficient (r) based on Rohlf and Sokal ${ }^{49}$. Principle 143 component analysis (PCA), and principle coordinate analysis (PCoA) to assess genetic diversity 144 were also calculated ${ }^{50}$. To evaluate genetic variance, analysis of molecular variance (AMOVA) ${ }^{51}$ 145 was carried out using GenAlEx version $6.4^{52}$. 


\section{Results}

\section{Statistics of DNA Marker Used in Genetic Diversity Assessment}

148 The ability to resolve genetic variation is directly related to the number of polymorphisms detected

149 by the marker system ${ }^{53}$. Table 2 indicates that the ISSR primers adequately reflect the 150 polymorphism present in the populations and were powerful enough to differentiate between 151 populations, indicating they were suitable for assessing genetic diversity of these populations ${ }^{53}$. 152 Against our A. retroflexus L. DNA, the 13 ISSR primers produced a total of 59 bands, of which 15358 were polymorphic. The number of polymorphic bands ranged from 3 (UBC822, UBC829, 154 UBC819, UBC833 and UBC817) to 13 (UBC810) (Table 2). The ISSR pattern obtained with 155 UBC810 primer is demonstrated in Supplemental Figure 1A. The A12 primer generated the 156 minimum polymorphism of $80 \%$ and primers AL1, UBC839, UBC810, UBC834, UBC829, 157 UBC818, UBC822, UBC811, UBC819, UBC815, UC833 and UC817 showed $100 \%$ 158 polymorphism. While the highest Rp and MRP value was recorded at 7.87 and 102.31 (UBC810), 159 the lowest was at 1.87 and 5.61 (UBC822), respectively. The EMR was the highest for UBC810 160 (13) and lowest for UBC822, UBC829, UBC819, UBC833 and UBC817 (3). Similarly, marker 161 index (MI) value was highest for UBC810 (5.21) and lowest for AL2 primer with 1.1. AL2 has the 162 lowest (1.8) observed number of alleles $(\mathrm{Na})$ and other primers (2) having the highest. The 163 effective number of allele $(\mathrm{Ne})$ was invariably less than $\mathrm{Na}$ values showing a variation in the range 164 of 1.44 (AL2) to 1.97 (UBC833). The Shannon index (I) estimates were low, ranging from 0.49 165 (AL2) to 0.68 (UBC833), as well as the estimates of Nei's genetic diversity, ranging from 0.34 166 (AL2) to 0.49 (UBC833) (Table 2A).

167 Moreover, the 13 selected primers generated 49 ISSR bands in the 17 C. album populations, 1683 to 8 bands per primer, of which 37 were polymorphic. The number of polymorphic bands varied 169 from 1 in Al2 and UBC811 to 7 in UBC810 (Table 2B). The ISSR pattern obtained with UBC810 170 primer is demonstrated in Supplemental Figure 1B. Al2 and UBC811 also provided the minimum 171 polymorphism of $33.33 \%$ and primers UBC839, UBC829, UBC818, UBC815 and UBC817 172 showed $100 \%$ polymorphism. The highest Rp and MRP value was in UBC810 primer (4.59 and 17332.13 respectively), and the lowest one in AL2 (0.35 and 0.35 respectively). The EMR was the 174 highest for UBC810 (6.12) and lowest for UBC839, UBC829, UBC818 and UBC817 (3). 175 Similarly, marker index (MI) value was highest for UBC810 (1.86) and lowest for AL2 and 
UBBC811 primers with 0.053 . AL2 and UBC811 have the lowest (1.3) observed number of alleles (Na) and UBC839, UBC829, UBC818, UBC815 and UBC817 (2) having the highest. The effective number of allele $(\mathrm{Ne})$ was invariably less than $\mathrm{Na}$ values showing a variation in the range of 1.13 (AL2) to 1.89 (UBC839). The Shannon index (I) ranging from 0.15 (AL2) to 0.66 (UBC839), as well as the estimates of Nei's genetic diversity, ranging from 0.09 (AL2) to 0.46 (UBC839 and UBC815) (Table 2B).

The PIC values ranged from 0.345 to 0.549 with the highest being for primer UBC834 and the lowest for primer AL2 for A. retroflexus L. (Table 2A). Furthermore, UBC834 primer with 0.09 and UBC817 primer with 0.48 showed the lowest and greatest PIC value among all primers for C. album populations, respectively (Table 2B). The average PIC value in both weed species indicated the selected ISSR primers was appropriate for the assessment of genetic diversity.

\section{Genetic Diversity and Population Structure of Amaranthus retroflexus L. and Chenopodium}

\section{album L.:}

This paper establishes the genetic diversity of Iranian A. retroflexus and C. album populations alongside French and Spanish populations using UPGMA clustering of the ISSR data .

Amaranthus retroflexus L.: The UPGMA clustering algorithm from ISSR analysis grouped the 16 A. retroflexus $\mathrm{L}$. populations into four distinct clusters at a similarity index value of 0.48 (Figure 1A). The calculated cophenetic correlation coefficient value ( $r$ ) of 0.78 indicates a high grouping efficiency. The first cluster consists of Rasht, Spain2, Ardabil and Moghan. The second group includes Rudsar, Sari, and Hamedan populations. The third cluster is populations from Shahre-eRey, Ilam, France, Gorgan, Spain1 and Spain3. The fourth group was formed of Yazd, Zarand and Bojnurd. Analysis of molecular variance confirmed the cut-off point of clustering (phipt=0.21) (Table 5A).

In the principle component analysis, the eigenvalues for the first three PCAs were 32.70, 18.02 and 15.45 , respectively which represents $66.17 \%$ of the total variation. The PCoA analysis showed four main clusters confirming the results of the UPGMA clustering (Figure 2A). The measurements of genetic diversity are summarized in Table 3A. The number of observed alleles and number of effective alleles ranged between 1.152-1.254 (Ilam or Yazd to Ardabil) and 1.0921.144 (Ilam or Yazd to Ardabil), respectively. The value of Nei's gene diversity ranged from 0.055 to 0.089 with the highest for Ardabil population and the lowest for Ilam and Yazd population 
among the 16 populations. The average of Shannon's Information Index for the 16 populations is

2070.11 which again the maximum and the minimum are respectively belonging to Ardail, Ilam or

208 Yazd populations. The highest number of polymorphic loci (PL) and percentage of polymorphic

209 loci (PPL) both belong to Ardail while the lowest, belongs to Ilam and Yazd. The values for total

210 species diversity for among population (HT), within population diversity (Hs) and mean

211 coefficient of gene differentiation (GST) were 0.429, 0.073 and 0.829, respectively. Furthermore,

212 the level of gene flow $(\mathrm{Nm})$ was estimated to be 0.102 individual per generation between

213 populations, suggesting that genetic exchange between populations was low. The highest genetic

214 identity is between Yazd and Zarand (0.79) with having the lowest genetic distance (0.22). The

215 maximum genetic distance is between Rasht and Zarand, moreover Rasht and Yazd (1.08) with

216 the minimum genetic identity of 0.33 (Table 4A).

217 Chenopodium album L.: The UPGMA dendrogram from ISSR analysis at a similarity index value

218 of 0.62 (Figure 1B). Cophenetic coefficient (r) of 0.71 indicates high grouping efficiency. The

219 populations were separated into four distinct clusters. Analysis of molecular variance confirmed

220 the cut-off point of clustering (phipt=0.31) (Table 5B): first cluster (Rudsar and Rasht), second

221 cluster (Boyer-Ahmad, Rudan, Tehran, Dehloran, Hamedan and Kivi), third cluster (Mashhad,

222 Spain1, Spain2 and France1), ultimately the fourth cluster is a representation of the populations

223 from Moghan, Ardabil, Yazdabad, Shahr-e-Rey and France2.

224 In the PCA analysis the eigenvalues for the first three components are 32.96, 21.26 and

225 17.21, respectively justified $71.43 \%$ of the total variation. The PCoA analysis showed four main

226 clusters confirming the results of the UPGMA clustering (Figure 2B). The measurements of

227 genetic diversity are summarized in Table 3B. The number of observed alleles and number of

228 observed effective alleles ranged between 1.122-1.183 (Spain1 to Kivi, Ardail, Yazdabad, Shahre-

229 Ray and Tehran) and 1.093-1.153 (Rudsar or Rudan to Yazdabad), respectively. The value of

230 Nei's gene diversity ranged from 0.052 to 0.82 with the highest for Yazdabad population and the

231 lowest for Spain1 population among the 17 populations. The average of Shannon's Information

232 Index for the 17 populations is 0.094 which the maximum and the minimum are respectively

233 belonging to Yazdabad- Spain1 populations. The highest number of polymorphic loci (PL) and

234 percentage of polymorphic loci (PPL) both belong to Kivi, Ardail, Yazdabad, Shahre-Ray and

235 Tehran while the lowest, belongs to Spain 1. The values for total species diversity for among 236 population (HT), within population diversity (Hs) and mean coefficient of gene differentiation 
237 (GST) were 0.36, 0.064 and 0.82, respectively. Furthermore, the level of gene flow (Nm) was 238 estimated to be 0.109 individuals per generation between populations, suggesting that gene 239 exchange between populations was low. Hamedan and Dehloran populations showed the highest 240 genetic identity )0.91) with having the lowest genetic distance (0.08). The maximum genetic 241 distance (0.71) and the minimum genetic identity (0.48) are between Ardabil and Rudsar along 242 with Ardabil and Rasht populations (Table 4B).

\section{Discussion}

244 Analysis of $A$. retroflexus or $C$. album using ISSR markers demonstrates there is a high genetic 245 diversity among the tested populations, suggesting that genetic exchange between populations was

246 low and variation between populations is more than within populations. Although UPGMA 247 clustering algorithm produced groupings, these did not correlate with geographic origin and the 248 Spanish and French populations grouped with the Iranian populations. Our data indicate that there 249 is little genetic exchange within populations of A. retroflexus or C. album in the populations 250 measured and suggest that the populations have been established long enough to allow for genetic 251 divergence to occur. Our results suggest the populations we have sampled may have been 252 separately introduced to their current locations probably through the activity of humans but have 253 not mixed significantly since.

254 The genetic analysis we performed with ISSR shows that A. retroflexus L. and C. album 255 L. populations from different regions have high level of genetic diversity among populations 256 compared to within populations. Mandal and Das ${ }^{54}$ and Transue et al. ${ }^{55}$ also reported a high genetic 257 diversity in Amaranthus using RAPD markers. Together these studies show that high levels of 258 genetic diversity may clarify the important role of geographic isolation during genetic 259 diversification and variation ${ }^{56}$. In principle, a high level of genetic diversity provides a varied 260 genetic toolbox that enables adaptation to an extensive range of ecosystems ${ }^{57}$. Conversely, low 261 genetic diversity within populations is what is expected from a mainly autogamous invasive 262 species $^{27}$, since self-fertilization reduces the proportion of heterozygous loci in individuals, 263 causing fixation of homozygous $\operatorname{loci}^{58}$. The genetic diversity of plant populations is mostly 264 affected by adaptive characteristics like the breeding system, seed dispersal, genetic drift, history 265 of introduction and therefore reflects how these have allowed plant morphology to adjust to 266 ecological conditions. Plant morphology, phenology and breeding system significantly influences 
genetic diversity where in general, long-lived and outcrossing species have higher levels of genetic 268 diversity than selfing and/or clonal plants ${ }^{59}$.

269 The genetic structure analysis (Figures 1 and 2) revealed high genetic differentiation 270 among the sampled locations. Analysis of molecular variance results indicate that most of the 271 genetic variation ( $\mathrm{FST}=0.71$ in A. retroflexus $\mathrm{L}$. and 0.7 in C. album L.) was found among 272 populations, consistent with the low intra-population analysis suggesting predominant self273 fertilization. The average value of FST for autogamous species using molecular markers is $0.70^{60}$. 274 Other autogamous species showed similar values of genetic differentiation to the measured mean 275 value ${ }^{61,62}$. The common restriction to gene flow ( $\mathrm{Nm}$ ) among populations usually results in a high 276 genetic divergence ${ }^{63}$. Because of the small number of sampled sites in our study, it is difficult to 277 accurately calculate genetic drift. A high number of private alleles was found in nearly all studied 278 locations (Table 2), indicating lack of gene flow between the populations. The presence of private 279 alleles is important because it may indicate disparate evolutionary paths ${ }^{64}$.

280 Knowledge of the spatial distribution of genetic diversity is essential to better comprehend 281 the relationships between life-history traits, stochastic effects, gene flow, selection pressures and 282 environmental factors ${ }^{65}$. We found no evidence of isolation by distance among the locations 283 sampled; although our limited sample size was perhaps too small to accurately conclude a 284 relationship between geographic and genetic distances. However, introduction and casual dispersal 285 events by human action frequently result in a lack of correlation between genetic and geographic 286 distances of invasive populations ${ }^{66}$. A. retroflexus $\mathrm{L}$. and C. album L. populations are most 287 commonly found on disturbed $\operatorname{areas}^{6}$, and therefore dispersal driven by human activity is likely in 288 these species. As a result, our lack of correlation between genetic and geographic distances of 289 populations implies that seed dispersal mechanisms and colonization history have influenced the 290 spatial distribution and genetic diversity we observed, similarly to other species ${ }^{67}$. This result also 291 emphasizes that the majority of these weed populations may have been established by distinct 292 introduction events.

293 Innovative weed control options can be helped by gaining a better understanding of the 294 genetic diversity of weed populations because genetic variability represents vital information about 295 historic bottleneck effects and diversification since establishment ${ }^{68,69}$. This new knowledge 296 provides a better understanding for how genetic variation exists and is essential to develop strategic 
297 and effective control practices for weeds as different responses to chemical or biological control 298 methods will be underpinned by differences in the weed genomes ${ }^{70}$.

299 In conclusion, the genetic diversity analyses using ISSR molecular markers revealed that 300 the studied populations of invasive A. retroflexus L. and C. album L. have low intra-population 301 genetic diversity and are divergent among each other. Self-fertilization, drift events, colonization

302 by few individuals, different selection pressures acting even within small geographic areas, and 303 distinct multiple introductions to the region may have influenced the genetic diversity of these 304 populations. These results are limited by the selected populations, which only cover Iran with 305 French and Spanish outgroups, therefore further study of invasive populations covering a wider 306 geographic distribution would be encouraged. As the chloroplast genome is maternally inherited, 307 does not recombine, and genetic diversity of different regions of the chloroplast genome varies 308 greatly, it would be useful for analysing phylogenetic relationships among species and evolution 309 rates. Therefore, analysis of the plastome or the use of co-dominant markers would enhance the 310 understanding of genetic diversity of these weed species allowing a better understanding of plant 311 dispersal mechanisms, gene flow and expand our knowledge of the genetics of weeds.

\section{Author Contributions}

313 SH performed the experiments, data collection, data analysis, figure preparation, and writing of 314 the manuscript. MA conceived the original data, formulated the research plan, oversaw the 315 research, and writing of the manuscript. MM, DM and TT contributed to data analysis and writing 316 of the manuscript. All authors contributed to the article and approved the submitted version.

\section{Acknowledgments}

318 This work was supported by the Faculty of Agriculture and Natural Sciences, University of 319 Mohaghegh Ardabili, Iran. DM was supported by the Smart Crop Protection Industrial Strategy 320 Challenge Fund (grant no. BBS/OS/CP/000001) from the Biotechnology and Biological Sciences 321 Research Council of the United Kingdom (BBSRC). TT was supported by the National Institute 322 of Food and Agriculture, United States Department of Agriculture, Hatch Project under accession 323 number 230100. 


\section{References}

1. Lee, C. E. Evolutionary genetics of invasive species. Trends Ecol Evol. 17, 386-391 (2002).

2. Ma, X., Wu, H., Jiang, W., Ma, Y. \& Ma, Y. Interference between Redroot Pigweed (Amaranthus retroflexus L.) and Cotton (Gossypium hirsutum L.): Growth Analysis. PloS one. 10, e0130475 (2015).

3. Bajwa, A. A., Zulfiqar, U., Sadia, S., Bhowmik, P., \& Chauhan, B. S. A global perspective on the biology, impact and management of Chenopodium album and Chenopodium murale: two troublesome agricultural and environmental weeds. Environ Sci Pollut Res Int. 26, 5357-5371 (2019).

4. Hamidzadeh Moghadam, S., Alebrahim, M.T., Tobeh, A., Mohebodini, M., Werck-Reichhart, D., \& et al. Redroot Pigweed (Amaranthus retroflexus L.) and Lamb's Quarters (Chenopodium album L.) Populations exhibit a high degree of morphological and biochemical diversity. Front. Plant Sci. 12, 39 (2021).

5. Horak, M. J. \& Loughin, T. M. Growth analysis of four Amaranthus species. Weed Sci. 48, 347355 (2000).

6. CABI. Invasive Species Compendium. Wallingford, UK: CAB International. https://www.cabi.org/isc (2020).

7. Holm, L., Doll, J., Holm, E., Pancho, J. \& Herberger, J. World weeds: Natural histories and distribution. (1th ed) 51-69 (John Wiley and Sons, 1997).

8. Knezevic, S. Z. \& Horak, M. J. Influence of emergence time and density on redroot pigweed (Amaranthus retrofexus). Weed Sci. 46, 665-672 (1998).

9. Telewski, F. W. \& Zeevaart, J. A. D. The 120-yr period for Dr. Beal's seed viability experiment. Am J Bot. 89, 1285-1288 (2002).

10. Brimhall, P. B., Chamberlain, E. W. \& Alley, H. P. Competition of annual weeds and sugarbeets. Weed Sci. 13: 33-35 (1965).

11. Dieleman, A., Hamil, A. S., Weise, S. F. \& Swanton, C. J. Empirical models of pigweed (Amaranthus spp.) interference in soybean (Glycine max). Weed Sci. 43, 612-618 (1995).

12. Weaver, S. E. Size-dependent economic thresholds for three broadleaf weed species in soybeans. Weed Technol. 5, 674-679 (1991). 
13. Alebrahim, M. T., Majd, R., Mohassel, M. H. R., Wilkakson, S., Baghestani, M. A. \& et al. Evaluating the efficacy of pre-and post-emergence herbicides for controlling Amaranthus retroflexus L. and Chenopodium album L. in potato. Crop Prot. 42, 345-350 (2012).

14. Buchanan, G. A., Crowley, R. H., Street, J. E. \& McGuire, J. M. Competition of sicklepod (Cassia obtusifolia L.) and redroot pigweed (Amaranthus retroflexus L.) with cotton (Gossypium hirsutum L.). Weed Sci. 28, 258-262 (1980).

15. Kenzevic, S. Z., Weise, S. F. \& Swanton, C. J. Comparison of empirical models depicting density of redroot pigweed (Amaranthus retroflexus L.) and relative leaf area as predictors of yield loss in maize (Zea mays L.). Weed Res. 35, 207-214 (1995).

16. Bhattacharjee, S. K. Handbook of medicinal plant. (3th rev.ed.) 1-2 (Pointer publishers, 2001).

17. Sarabi, V., Mahallati, M. N., Nezami, A. \& Mohassel, M. H. R. Effects of common lambsquarters (Chenopodium album L.) emergence time and density on growth and competition of maize (Zea mays L.). Aust J Crop Sci. 7, 532-537 (2013).

18. Jabran, K., Mahmood, K., Melander, M., Bajwa, A. A. \& Kudsk, P. Weed dynamics and management in wheat. Adv Agron. 145, 97-166 (2017).

19. Toole, E. H. \& Brown, E. Final results of the Duval buried seed experiment. J Agric Res. 72, 201210 (1946).

20. Holm, L. G., Plucknett, D. L., Pancho, J. V. \& Herberger, J. P. (1977). The world's worst weeds. Distribution and Biology. 609 (East-West Center and University Press of Hawaii, 1977)

21. Maurya, A. N. \& Ambasht, R. S. Significance of seed dimorphism in Alysicarpus monilifer DC. J Ecol. 61, 213-217 (1973).

22. Sakai, A. K., Allendorf, F. W., Holt, J. S., Lodge, D. M. Molofsky, J. \& et al. The population biology of invasive species. Annu Rev Ecol Evol Syst. 32, 305-332 (2001).

23. Alebrahim, M. T., Mohassel, M. H. R., Wilkakson, S., Baghestani, M. A., \& Ghorbani, R. Evaluating of some preemergence herbicides for lambsquarter and redroot pigweed control in potato fields. J. Plant Prot. 25: 358-367 (2012).

24. te Beest, M., Le Roux, J. J., Richardson, D. M., Brysting, A. K., Suda, J. \& et al. (2012). The more the better? The role of polyploidy in facilitating plant invasions. Ann Bot. 109, 19-45.

25. Ma, J. W., Geng, S. L., Wang, S. B., Zhang, G. L., Fu, W. D. \& Shu, B. Genetic diversity of the newly invasive weed Flaveria bidentis (Asteraceae) reveals consequences of its rapid range expansion in northern China. Weed Res. 51, 363-372 (2011).. 
26. Keller, S. R. \& Taylor, D. R. History, chance and adaptation during biological invasion: separating stochastic phenotypic evolution from response to selection. Ecol Lett. 11, 852-866 (2008).

27. Barrett, S. C. H., Colautti, R. I. \& Eckert, C.G. Plant reproductive systems and evolution during biological invasion. Mol Ecol. 17, 373-383 (2008).

28. Parita, B., Kumar, S. N., Darshan, D. \& Karen, P. Elucidation of genetic diversity among ashwagandha [Withania somnifera (L.) Dunal] genotypes using EST-SSR markers. Res $J$ Biotechnol. 13, 52-59 (2018).

29. Wolfe, A. D., Xiang, Q. Y. \& Kephart, S. R. Assessing hybridization in natural populations of Penstemon (Scrophulariaceae) using hypervariable intersimple sequence repeat (ISSR) bands. Mol Ecol. 7, 1107-1125 (1998).

30. Raut, V. R., Dodake, S. S. \& Chimote, V. P. Evaluation of genetic diversity in grain amaranth (Amaranthus hypochondriacus) at molecular level using ISSR markers. Indian J Agric Biochem. 27, 60-65 (2014).

31. Stefunova, V., Bezo, M., Labajová, M., \& Senková, S. Genetic analysis of three Amaranth species using ISSR markers. Emir J Food Agric. 26, 35-44 (2014).

32. Mukherjee, K. K. A comparative study of two cytotypes of Chenopodium album in West Bengal, India. Can J Bot. 64: 754-759 (1986).

33. Kolano, B., Plucienniczak, A., Kwasniewski, M. \& Maluszynska, J. Chromosomal localization of a novel repetitive sequence in the Chenopodium quinoa genome. J Appl Genet. 49, 313-320 (2008).

34. Rahiminejad, M. R. \& Gornall, R. J. Flavonoid, evidence for allopolyploidy in the Chenopodium album aggregate (Amaranthaceae). Plant Syst Evol. 246, 77-87 (2004).

34. Rana, T. S., Narzary, D. \& Ohri, D. Genetic diversity and relationships among some wild and cultivated species of Chenopodium L. (Amaranthaceae) using RAPD and DAMD methods. Curr Sci. 98, 840-846 (2010).

35. Rana, T. S., Narzary, D. \& Ohri, D. Molecular differentiation of Chenopodium album complex and some related species using ISSR profiles and ITS sequences. Gene. 495, 29-35 (2012).

36. Mandák, B., Zákravský, P., Dostál, P., \& Plačková, I. Population genetic structure of the noxious weed Amaranthus retroflexus in Central Europe. Flora. 206, 697-703 (2011).

37. Alebrahim, M. T., Zangoueinejad, R. \& Tseng, T.M. Biochemical and molecular knowledge about developing herbicide-resistant weeds. 101-132 (Herbicide resistance in weeds and crops, 2017). 
38. Azadbakht, A., Alebrahim, M. T. \& Ghavidel, A. The effect of chemical and nonchemical control methods on weeds in potato (solanum tuberosum L.) cultivation in Ardabil province, Iran. Appl Ecol Environ Res. 15, 1359-1372 (2017).

39. Saghai-Maroof, M. A., Soliman, K. M., Jorgensen, R. A. \& Allard, R. W. Ribosomal DNA sepacer-length polymorphism in barley: mendelian inheritance, chromosomal location, and population dynamics. Proc Natl Acad Sci. 81, 8014-8019 (1984).

40. Prevost, A. \& Wilkinson, M. J. A new system of comparing PCR primers applied to ISSR fingerprinting of potato cultivars. Theor Appl Genet. 98, 107-112 (1999).

41. Milbourne, D., Meyer, R., Bradshaw, J., Baird, E., Bonar, N. \& et al. Comparisons of PCR-based marker systems for the analysis of genetic relationships in cultivated potato. Mol Breeding. 3, 127136 (1997).

42. Roldán-Ruiz, I., Dendauw, J., Bockstaele, E. V., Depicker, A. \& Loose, M. D. AFLP markers reveal high polymorphic rates in ryegrasses (Lolium Spp). Mol Breed. 6, 125-134 (2000).

43. Powell, W., Morgante, M., Andre, C., Hanafey, M., Vogel, J. \& et al. The comparison of RFLP, AFLP and SSR (microsatellite) markers for germplasm analysis. Mol Breed. 2, 225-238 (1996).

44. Yeh, F.C. \& Boyle, T. J. B. Population genetic analysis of codominant and dominant markers and quantitative traits. Belg J Bot. 129, 157-163 (1997).

45. McDermott, J. M., \& McDonald, B. A. Gene flow in plant pathosystems. Annu Rev Phytopathol. 31, 353-373s (1993).

46. Nei, M. Estimation of average heterozygosity and genetic distance from a small number of individuals. Genetics. 89, 583-590 (1978).

47. Rohlf, F. J. NTSYS-pc. Numerical taxonomy and multivariate analysis system. Version 2.1. (Exeter Software, 2000).

48. Saracli, S., Dogan, N. \& Dogan, I. Comparison of hierarchical cluster analysis methods by cophenetic correlation. J Inequal Appl. 203, 1-8 (2013).

49. Rohlf, F. J. \& Sokal, R. R. (1981). Comparing numerical taxonomic studies. Syst Zool. 30, 459490.

50. Mohammadi, S. A. \& Prasanna, B. M. Analysis of genetic diversity in crop plants-salient statistical tools and considerations. Crop Sci. 43, 1235-1248 (2003). 
51. Excoffier, L., Smouse, P. \& Quattro, J. Analysis of molecular variance inferred for metric distances among DNA haplotypes: application to human mitochondrial DNA restriction data. Genetics. 131, 479-491 (1992).

52. Peakall, R. \& Smouse, P. E. GENALEX 6: genetic analysis in excel. Population genetic software for teaching and research. Mol Ecol Notes. 6, 288-295 (2006).

53. Sivaprakash, K. R., Prasanth, S. R., Mohanty, B. P. \& Parida, A. Genetic diversity of black gram (Vigna mungo) landraces as evaluated by amplified fragment length polymorphism markers. Curr Sci. 86, 1411-1415 (2004).

54. Mandal, N. \& Das, P. K. Intra- and interspecific genetic diversity in grain Amaranthus using random amplified polymorphic DNA markers. Plant Tissue Cult. 12, 49-56 (2002).

55. Transue, D. K., Fairbanks, D. J., Robison, L. R., \& Andersen, W. R. Species identification by RAPD analysis of grain amaranth genetic resources. Crop Sci. 34, 1385-1389 (1994).

56. Guo, H. B., Li, S. M., Peng, J. \& Ke, W. D. Genetic diversity of Nelumbo accessions revealed by RAPD. Genet Resour Crop Evol. 54, 741-748 (2007).

57. Dekker, J. Weed diversity and weed management. Weed Sci. 37, 357-363 (1997).

58. Hamilton, M. B. Population genetics. (1th ed). 373-383 (Wiley- Blackwell publishing, 2009).

59. Hamrick, J. L. \& Godt, M. J. W. Effects of life history traits on genetic diversity in plant species. Philos Trans R Soc Lond B Biol Sci. 351, 1291-1298 (1996).

60. Nybom, H. \& Bartish, I. V. (2000). Effects of life history traits and sampling strategies on genetic diversity estimates obtained with RAPD markers in plants. Perspect. Plant Ecol Evol. 3, 93-114.

61. Ueno, S., Rodrigues, J. F., Alves-Pereira, A., Pansarin, E. R. \& Veasey, E. A. Genetic variability within and among populations of an invasive, exotic orchid. AoBP. 7: plv077 (2015).

62. Aguayo, J., Adams, G. C., Halkett, F., Catal, M., Husson, C., Nagy, Z. A., Hansen, E. M., Marcais, B. \& Frey, P. Strong genetic differentiation between North American and European populations of Phytophthora alni subsp. uniformis. Phytopathology. 103, 190-199 (2013).

64. Yang, M., Liu, F., Han, Y., Xu, L., Juntawong, N., \& Liu, Y. Genetic diversity and structure in populations of Nelumbo from America, Thailand and China: implications for conservation and breeding. Aquat Bot. 107, 1-7 (2013).

65. Escudero, A., Iriondo, J. M. \& Torres, E. Spatial analysis of genetic diversity as a tool for plant conservation. Biol Conserv. 113, 351-365 (2003). 
66. Guggisberg, A., Welk, E., Sforza, R., Horvath, D. P., Anderson, J. V., Foley, M. E. \& Rieseberg, L.H. Invasion history of North American Canada thistle, Cirsium arvense. J. Biogeogr. 39, 19191931 (2012).

67. Heywood, V. H., Brummitt, R. K., Culham, A. \& Seberg, O. Flowering plant families of the world. Curtis's bot mag. 24, 198-200 (2007).

68. Goolsby, J. A., De Barro, P. J., Makinson, J. R., Pemberton, R. W., Hartley, D. M. \& Frohlich, D. R. Matching the origin of an invasive weed for selection of a herbivore haplotype for a biological control program. Mol Ecol. 15, 287-297 (2006).

69. Slotta, T. A. B. What we know about weeds: insights from genetic markers. Weed Sci. 56, 322326 (2008).

70. Arias, R. S., Molin, W. T., Ray, J. D., Peel, M. \& Scheffler, B. E. Isolation and characterisation of the first microsatellite markers for Cyperus rotundus. Weed Res. 51: 451-460 (2011). 
Table 1. The list of 16 Amaranthus retroflexus and 17 Chenopodium album populations evaluated in this study with their coordinate and origin names with their coordinate and origin names

\begin{tabular}{|c|c|c|c|c|}
\hline \multicolumn{5}{|c|}{ A. retroflexus } \\
\hline No. & Region name & Origin & Latitude $(\mathrm{N})$ & Longitude (E) \\
\hline 1 & Rasht & Iran & $37^{\circ} 16^{\prime} 05 \mathrm{~N}$ & $49^{\circ} 35^{\prime} 20 \mathrm{E}$ \\
\hline 2 & Gorgan & Iran & $36^{\circ} 45^{\prime} 06 \mathrm{~N}$ & $54^{\circ} 21^{\prime} 40 \mathrm{E}$ \\
\hline 3 & Rudsar & Iran & $37^{\circ} 08^{\prime} 16 \mathrm{~N}$ & $50^{\circ} 17^{\prime} 10 \mathrm{E}$ \\
\hline 4 & Sari & Iran & $36^{\circ} 33^{\prime} 57 \mathrm{~N}$ & $53^{\circ} 03^{\prime} 31 \mathrm{E}$ \\
\hline 5 & Shahr-e-Rey & Iran & $35^{\circ} 34^{\prime} 37 \mathrm{~N}$ & $51^{\circ} 27^{\prime} 44 \mathrm{E}$ \\
\hline 6 & Ilam & Iran & $33^{\circ} 38^{\prime} 05 \mathrm{~N}$ & $46^{\circ} 24^{\prime} 54 \mathrm{E}$ \\
\hline 7 & Yazd & Iran & $31^{\circ} 10^{\prime} 97 \mathrm{~N}$ & $53^{\circ} 11^{\prime} 97 \mathrm{E}$ \\
\hline 8 & Bojnurd & Iran & $37^{\circ} 53^{\prime} 74 \mathrm{~N}$ & $57^{\circ} 24^{\prime} 96 \mathrm{E}$ \\
\hline 9 & Zarand & Iran & $30^{\circ} 47^{\prime} 27 \mathrm{~N}$ & $56^{\circ} 50^{\prime} 10 \mathrm{E}$ \\
\hline 10 & Hamedan & Iran & $34^{\circ} 47^{\prime} 50 \mathrm{~N}$ & $48^{\circ} 30^{\prime} 45 \mathrm{E}$ \\
\hline 11 & Ardabil & Iran & $38^{\circ} 14^{\prime} 54 \mathrm{~N}$ & $48^{\circ} 17^{\prime} 03 \mathrm{E}$ \\
\hline 12 & Moghan & Iran & $39^{\circ} 13^{\prime} 00 \mathrm{~N}$ & $47^{\circ} 33 ' 53 \mathrm{E}$ \\
\hline 13 & France & France & $47^{\circ} 19^{\prime} 20 \mathrm{~N}$ & $5^{\circ} 2 ' 28 \mathrm{E}$ \\
\hline 14 & Spain 1 & Spain & $37^{\circ} 53^{\prime} 18 \mathrm{~N}$ & $4^{\circ} 46^{\prime} 38 \mathrm{~W}$ \\
\hline 15 & Spain 2 & Spain & $37^{\circ} 53^{\prime} 15 \mathrm{~N}$ & $4^{\circ} 46^{\prime} 35 \mathrm{~W}$ \\
\hline 16 & Spain 3 & Spain & $37^{\circ} 53^{\prime} 14 \mathrm{~N}$ & $4^{\circ} 46^{\prime} 45 \mathrm{~W}$ \\
\hline \multicolumn{5}{|c|}{ C. album } \\
\hline 1 & Rudsar & Iran & $37^{\circ} 08^{\prime} 13 \mathrm{~N}$ & $50^{\circ} 16^{\prime} 52 \mathrm{E}$ \\
\hline 2 & Rasht & Iran & $37^{\circ} 16^{\prime} 03 \mathrm{~N}$ & $49^{\circ} 35^{\prime} 08 \mathrm{E}$ \\
\hline 3 & Boyer-Ahmad & Iran & $30^{\circ} 53^{\prime} 47 \mathrm{~N}$ & $51^{\circ} 24^{\prime} 96 \mathrm{E}$ \\
\hline 4 & Rudan & Iran & $27^{\circ} 25^{\prime} 44 \mathrm{~N}$ & $57^{\circ} 10^{\prime} 45 \mathrm{E}$ \\
\hline 5 & Moghan & Iran & $39^{\circ} 12^{\prime} 03 \mathrm{~N}$ & $47^{\circ} 34^{\prime} 24 \mathrm{E}$ \\
\hline 6 & Kivi & Iran & $37^{\prime} 41^{\prime} 02 \mathrm{~N}$ & $48^{\circ} 20^{\prime} 53 \mathrm{E}$ \\
\hline 7 & Ardabil & Iran & $38^{\circ} 12^{\prime} 44 \mathrm{~N}$ & $48^{\circ} 17^{\prime} 38 \mathrm{E}$ \\
\hline 8 & Yazdabad & Iran & $32^{\circ} 39^{\prime} 41 \mathrm{~N}$ & $51^{\circ} 41^{\prime} 21 \mathrm{E}$ \\
\hline 9 & Shahr-e-Ray & Iran & $35^{\circ} 34^{\prime} 22 \mathrm{~N}$ & $51^{\circ} 27^{\prime} 44 \mathrm{E}$ \\
\hline 10 & Tehran & Iran & $35^{\circ} 41^{\prime} 13 \mathrm{~N}$ & $51^{\circ} 26^{\prime} 22 \mathrm{E}$ \\
\hline 11 & Dehloran & Iran & $32^{\circ} 41^{\prime} 49 \mathrm{~N}$ & $47^{\circ} 16^{\prime} 05 \mathrm{E}$ \\
\hline 12 & Hamadan & Iran & $34^{\circ} 49^{\prime} 46 \mathrm{~N}$ & $48^{\circ} 19^{\prime} 47 \mathrm{E}$ \\
\hline 13 & Mashhad & Iran & $36^{\circ} 16^{\prime} 24 \mathrm{~N}$ & $59^{\circ} 38^{\prime} 16 \mathrm{E}$ \\
\hline 14 & Spain 1 & Spain & $37^{\circ} 53^{\prime} 15 \mathrm{~N}$ & $4^{\circ} 46^{\prime} 35 \mathrm{~W}$ \\
\hline 15 & Spain 2 & Spain & $37^{\circ} 53^{\prime} 14 \mathrm{~N}$ & $4^{\circ} 46^{\prime} 45 \mathrm{~W}$ \\
\hline 16 & France 1 & France & $47^{\circ} 19^{\prime} 20 \mathrm{~N}$ & $5^{\circ} 2 ' 28 \mathrm{E}$ \\
\hline 17 & France 2 & France & $47^{\circ} 19^{\prime} 29 \mathrm{~N}$ & $5^{\circ} 2^{\prime} 22 \mathrm{E}$ \\
\hline
\end{tabular}


Table 2. Data of ISSR primers of 13 primers in Amaranthus retroflexus (A) and Chenopodium album (B) populations

A)

\begin{tabular}{|c|c|c|c|c|c|c|c|c|c|c|c|c|c|c|c|}
\hline $\begin{array}{c}\text { Primer } \\
\text { name }\end{array}$ & Primer seq & $\mathrm{Tm}$ & NT & NP & PP & $\beta$ & PIC & EMR & MI & $\mathrm{RP}$ & MRP & $\mathrm{Na}$ & $\mathrm{Ne}$ & $\mathrm{H}$ & I \\
\hline AL-1 & (GA)6CC & 43.7 & 6 & 6 & 100 & 1 & 0.378 & 6 & 2.26 & 3.25 & 19.5 & 2 & 1.63 & 0.4 & 0.55 \\
\hline AL-2 & $\mathrm{GA}(\mathrm{GGA}) 2 \mathrm{GGC}$ & 38 & 5 & 4 & 80 & 0.8 & 0.345 & 3.2 & 1.1 & 2.625 & 10.5 & 1.8 & 1.44 & 0.34 & 0.49 \\
\hline UBC839 & (AC) $8 \mathrm{GA}$ & 53 & 4 & 4 & 100 & 1 & 0.449 & 4 & 1.79 & 3 & 12 & 2 & 1.81 & 0.44 & 0.63 \\
\hline UBC 810 & (GA)8T & 52 & 13 & 13 & 100 & 1 & 0.401 & 13 & 5.21 & 7.87 & 102.31 & 2 & 1.71 & 0.37 & 0.58 \\
\hline UBC834 & (AG)8YT & 54 & 4 & 4 & 100 & 1 & 0.549 & 4 & 2.19 & 2.25 & 9 & 2 & 1.62 & 0.36 & 0.54 \\
\hline UBC829 & (TG)8C & 49 & 3 & 3 & 100 & 1 & 0.445 & 3 & 1.335 & 2.125 & 6.375 & 2 & 1.81 & 0.44 & 0.63 \\
\hline UBC818 & (CA)8G & 42 & 4 & 4 & 100 & 1 & 0.449 & 4 & 1.796 & 3 & 12 & 2 & 1.82 & 0.44 & 0.63 \\
\hline UBC822 & (TC) $8 \mathrm{~A}$ & 49 & 3 & 3 & 100 & 1 & 0.401 & 3 & 1.203 & 1.87 & 5.61 & 2 & 1.73 & 0.39 & 0.57 \\
\hline UBC811 & $(\mathrm{GA}) 8 \mathrm{C}$ & 52.4 & 4 & 4 & 100 & 1 & 0.395 & 4 & 1.58 & 2.5 & 10 & 2 & 1.68 & 0.39 & 0.57 \\
\hline UBC819 & (GT)8A & 52.4 & 3 & 3 & 100 & 1 & 0.466 & 3 & 1.398 & 2.37 & 7.11 & 2 & 1.87 & 0.46 & 0.65 \\
\hline UBC815 & $(\mathrm{CT}) 8 \mathrm{G}$ & 52 & 4 & 4 & 100 & 1 & 0.465 & 4 & 1.86 & 3 & 12 & 2 & 1.86 & 0.45 & 0.65 \\
\hline UBC833 & (AT) $8 \mathrm{YG}$ & 54 & 3 & 3 & 100 & 1 & 0.495 & 3 & 1.485 & 2.75 & 8.25 & 2 & 1.97 & 0.49 & 0.68 \\
\hline UBC817 & $(\mathrm{CA}) 8 \mathrm{~A}$ & 49 & 3 & 3 & 100 & 1 & 0.458 & 3 & 1.374 & 2.5 & 7.5 & 2 & 1.86 & 0.45 & 0.64 \\
\hline Mean & - & - & 4.54 & 4.46 & 98.46 & 0.98 & 0.44 & 4.4 & 1.89 & 3.01 & 17.09 & 1.98 & 1.75 & 0.42 & 0.6 \\
\hline $\begin{array}{l}\text { Primer } \\
\text { name }\end{array}$ & Primer seq & $\mathrm{Tm}$ & NT & NP & PP & $\beta$ & PIC & EMR & MI & $\mathrm{RP}$ & MRP & $\mathrm{Na}$ & $\mathrm{Ne}$ & $\mathrm{H}$ & I \\
\hline AL-1 & (GA)6CC & 43.7 & 4 & 3 & 75 & 0.75 & 0.327 & 2.25 & 0.736 & 2 & 6 & 1.75 & 1.54 & 0.29 & 0.43 \\
\hline AL-2 & GA(GGA)2GGC & 38 & 3 & 1 & 33.33 & 0.33 & 0.162 & 0.33 & 0.053 & 0.35 & 0.35 & 1.33 & 1.13 & 0.09 & 0.15 \\
\hline UBC839 & (AC)8GA & 53 & 3 & 3 & 100 & 1 & 0.453 & 3 & 1.359 & 2.47 & 7.41 & 2 & 1.89 & 0.46 & 0.66 \\
\hline UBC810 & $(\mathrm{GA}) 8 \mathrm{~T}$ & 52 & 8 & 7 & 87.5 & 0.87 & 0.304 & 6.12 & 1.860 & 4.59 & 32.13 & 1.87 & 1.64 & 0.35 & 0.52 \\
\hline UBC834 & $(\mathrm{AG}) 8 \mathrm{YT}$ & 54 & 5 & 3 & 60 & 0.6 & 0.09 & 1.8 & 0.162 & 0.94 & 2.82 & 1.6 & 1.21 & 0.156 & 0.25 \\
\hline UBC829 & (TG)8C & 49 & 3 & 3 & 100 & 1 & 0.266 & 3 & 0.798 & 1.76 & 5.28 & 2 & 1.68 & 0.39 & 0.58 \\
\hline UBC818 & $(\mathrm{CA}) 8 \mathrm{G}$ & 42 & 3 & 3 & 100 & 1 & 0.463 & 3 & 1.389 & 2.24 & 6.72 & 2 & 1.82 & 0.44 & 0.63 \\
\hline UBC822 & (TC) $8 \mathrm{~A}$ & 49 & 3 & 2 & 66.66 & 0.66 & 0.267 & 1.33 & 0.355 & 1.06 & 2.12 & 1.66 & 1.41 & 0.24 & 0.6 \\
\hline UBC811 & $(\mathrm{GA}) 8 \mathrm{C}$ & 52.4 & 3 & 1 & 33.33 & 0.33 & 0.161 & 0.33 & 0.053 & 0.71 & 0.71 & 1.3 & 1.28 & 0.15 & 0.21 \\
\hline UBC819 & (GT)8A & 52.4 & 3 & 2 & 66.66 & 0.66 & 0.24 & 1.33 & 0.319 & 0.94 & 1.88 & 1.66 & 1.37 & 0.23 & 0.36 \\
\hline UBC815 & $(\mathrm{CT}) 8 \mathrm{G}$ & 52 & 4 & 4 & 100 & 1 & 0.362 & 4 & 1.448 & 3.06 & 12.24 & 2 & 1.88 & 0.46 & 0.65 \\
\hline UBC833 & (AT) $8 Y G$ & 54 & 4 & 2 & 50 & 0.5 & 0.237 & 1 & 0.237 & 0.82 & 1.64 & 1.5 & 1.24 & 0.15 & 0.24 \\
\hline UBC817 & $(\mathrm{CA}) 8 \mathrm{~A}$ & 49 & 3 & 3 & 100 & 1 & 0.481 & 3 & 1.443 & 2 & 6 & 2 & 1.77 & 0.42 & 0.61 \\
\hline Mean & - & - & 3.77 & 2.85 & 74.81 & 0.75 & 0.29 & 2.35 & 0.79 & 1.76 & 6.56 & 1.74 & 1.53 & 0.29 & 0.45 \\
\hline
\end{tabular}

melting temperature (Tm), number of total bands (NT), number of polymorphic bands (NP), percentage of polymorphic fragment (PP), polymorphic information content (PIC), effective multiplex ratio (EMR), marker index (MI), resolving power (RP), mass resolving power (MRP), number of observed alleles (Na), number of effective alleles (Ne), Nei's gene diversity (H), Shannon's information index (I) 
Table 3. Genetic diversity data of 16 Amaranthus retroflexus (A) and 17 Chenopodium album (B) populations

(A)

\begin{tabular}{|c|c|c|c|c|c|c|c|c|c|c|c|}
\hline population & $\mathrm{Na}$ & $\mathrm{Ne}$ & $\mathrm{H}$ & $\mathrm{I}$ & $\mathrm{PL}$ & PPL & $\mathrm{Ht}$ & $\mathrm{Hs}$ & Gst & $\mathrm{Nm}$ & Fst \\
\hline Rasht & 1.203 & 1.131 & 0.076 & 0.114 & 12 & 20.34 & & & & & \\
\hline Gorgan & 1.186 & 1.106 & 0.065 & 0.099 & 11 & 18.64 & & & & & \\
\hline Rudsar & 1.203 & 1.122 & 0.073 & 0.11 & 12 & 20.34 & & & & & \\
\hline Sari & 1.22 & 1.138 & 0.082 & 0.122 & 13 & 22.03 & & & & & \\
\hline Shahr-e-Rey & 1.169 & 1.108 & 0.063 & 0.094 & 10 & 16.95 & & & & & \\
\hline Ilam & 1.152 & 1.092 & 0.055 & 0.083 & 9 & 15.25 & & & & & \\
\hline Yazd & 1.152 & 1.092 & 0.055 & 0.083 & 9 & 15.25 & & & & & \\
\hline Bojnurd & 1.203 & 1.131 & 0.076 & 0.114 & 12 & 20.34 & & & & & \\
\hline Zarand & 1.186 & 1.133 & 0.075 & 0.109 & 11 & 18.64 & & & & & \\
\hline Hamedan & 1.237 & 1.137 & 0.083 & 0.127 & 14 & 23.73 & & & & & \\
\hline Ardabil & 1.254 & 1.144 & 0.089 & 0.135 & 15 & 25.42 & & & & & \\
\hline Moghan & 1.22 & 1.112 & 0.072 & 0.112 & 13 & 22.03 & & & & & \\
\hline France & 1.203 & 1.113 & 0.07 & 0.107 & 12 & 20.34 & & & & & \\
\hline Spain 1 & 1.203 & 1.113 & 0.076 & 0.114 & 12 & 20.34 & & & & & \\
\hline Spain 2 & 1.22 & 1.138 & 0.082 & 0.122 & 13 & 22.03 & & & & & \\
\hline Spain 3 & 1.203 & 1.113 & 0.07 & 0.107 & 12 & 20.34 & & & & & \\
\hline Mean & 1.201 & 1.12 & 0.073 & 0.11 & - & - & & & & & \\
\hline Total & 2 & 1.784 & 0.429 & 0.616 & 59 & 100 & 0.429 & 0.073 & 0.829 & 0.102 & 0.71 \\
\hline
\end{tabular}

(B)

\begin{tabular}{|c|c|c|c|c|c|c|c|c|c|c|c|}
\hline population & $\mathrm{Na}$ & $\mathrm{Ne}$ & $\mathrm{H}$ & $\mathrm{I}$ & $\mathrm{PL}$ & PPL & $\mathrm{Ht}$ & $\mathrm{Hs}$ & Gst & $\mathrm{Nm}$ & Fst \\
\hline Rudsar & 1.142 & 1.093 & 0.054 & 0.08 & 7 & 14.29 & & & & & \\
\hline Rasht & 1.142 & 1.104 & 0.058 & 0.084 & 7 & 14.29 & & & & & \\
\hline Boyer-Ahmad & 1.163 & 1.123 & 0.068 & 0.098 & 8 & 16.33 & & & & & \\
\hline Rudan & 1.142 & 1.093 & 0.054 & 0.08 & 7 & 14.29 & & & & & \\
\hline Moghan & 1.163 & 1.123 & 0.068 & 0.098 & 8 & 16.33 & & & & & \\
\hline Kivi & 1.183 & 1.132 & 0.074 & 0.108 & 9 & 18.37 & & & & & \\
\hline Ardabil & 1.183 & 1.132 & 0.074 & 0.108 & 9 & 18.37 & & & & & \\
\hline Yazdabad & 1.183 & 1.153 & 0.082 & 0.116 & 9 & 18.37 & & & & & \\
\hline Shahr-e-Ray & 1.183 & 1.142 & 0.078 & 0.112 & 9 & 18.37 & & & & & \\
\hline Tehran & 1.183 & 1.11 & 0.066 & 0.1 & 9 & 18.37 & & & & & \\
\hline Dehloran & 1.163 & 1.112 & 0.064 & 0.09 & 8 & 16.33 & & & & & \\
\hline Hamadan & 1.163 & 1.102 & 0.065 & 0.09 & 8 & 16.33 & & & & & \\
\hline Mashhad & 1.142 & 1.104 & 0.058 & 0.084 & 7 & 14.29 & & & & & \\
\hline Spain 1 & 1.122 & 1.095 & 0.052 & 0.075 & 6 & 12.24 & & & & & \\
\hline Spain 2 & 1.163 & 1.112 & 0.064 & 0.094 & 8 & 16.33 & & & & & \\
\hline France 1 & 1.63 & 1.123 & 0.068 & 0.098 & 8 & 16.33 & & & & & \\
\hline France 2 & 1.163 & 1.104 & 0.058 & 0.084 & 7 & 14.29 & & & & & \\
\hline Mean & 1.189 & 1.115 & 0.065 & 0.094 & - & - & & & & & \\
\hline Total & 1.959 & 1.636 & 0.36 & 0.531 & 47 & 95.92 & 0.36 & 0.064 & 0.82 & 0.109 & 0.7 \\
\hline
\end{tabular}

number of observed alleles $(\mathrm{Na})$, number of effective alleles $(\mathrm{Ne})$, Nei's gene diversity $(\mathrm{H})$, Shannon's information index (I), number of polymorphic loci (PL), percentage of polymorphic loci (PPL), total population diversity for within population (Hs), among population diversity (Ht), coefficient of gene differentiation (Gst), gene flow (Nm), fixation index (Fst). 
Table 4. Nei's unbiased measures of genetic identity (above diagonal) and genetic distance (below diagonal) primers in Amaranthus retroflexus (A) and Chenopodium album (B)

A)

\begin{tabular}{|c|c|c|c|c|c|c|c|c|c|c|c|c|c|c|c|c|}
\hline A. retroflexus & Rasht & Gorgan & Rudsar & Sari & $\begin{array}{c}\text { Shahr-e- } \\
\text { Rey }\end{array}$ & Ilam & Yazd & Bojnurd & Zarand & Hamedan & Ardabil & Moghan & France & Spain 1 & Spain 2 & Spain 3 \\
\hline Rasht & 1 & 0.72 & 0.71 & 0.64 & 0.5 & 0.49 & 0.33 & 0.47 & 0.33 & 0.59 & 0.71 & 0.55 & 0.47 & 0.47 & 0.59 & 0.59 \\
\hline Gorgan & 0.31 & 1 & 0.71 & 0.61 & 0.61 & 0.42 & 0.37 & 0.5 & 0.44 & 0.52 & 0.67 & 0.52 & 0.54 & 0.47 & 0.62 & 0.62 \\
\hline Rudsar & 0.33 & 0.33 & 1 & 0.72 & 0.45 & 0.47 & 0.35 & 0.45 & 0.38 & 0.61 & 0.66 & 0.5 & 0.52 & 0.49 & 0.61 & 0.54 \\
\hline Sari & 0.44 & 0.49 & 0.31 & 1 & 0.45 & 0.61 & 0.42 & 0.49 & 0.38 & 0.67 & 0.66 & 0.61 & 0.55 & 0.49 & 0.54 & 0.61 \\
\hline Shahr-e-Rey & 0.67 & 0.49 & 0.78 & 0.78 & 1 & 0.61 & 0.49 & 0.62 & 0.59 & 0.54 & 0.49 & 0.4 & 0.66 & 0.49 & 0.67 & 0.61 \\
\hline Ilam & 0.71 & 0.85 & 0.74 & 0.49 & 0.49 & 1 & 0.47 & 0.5 & 0.5 & 0.62 & 0.57 & 0.62 & 0.54 & 0.5 & 0.55 & 0.62 \\
\hline Yazd & 1.08 & 0.98 & 1.03 & 0.85 & 0.71 & 0.74 & 1 & 0.76 & 0.79 & 0.47 & 0.38 & 0.5 & 0.52 & 0.52 & 0.47 & 0.5 \\
\hline Bojnurd & 0.74 & 0.67 & 0.78 & 0.71 & 0.46 & 0.67 & 0.27 & 1 & 0.72 & 0.61 & 0.52 & 0.5 & 0.66 & 0.62 & 0.61 & 0.61 \\
\hline Zarand & 1.08 & 0.81 & 0.94 & 0.94 & 0.52 & 0.67 & 0.22 & 0.31 & 1 & 0.37 & 0.35 & 0.44 & 0.52 & 0.45 & 0.47 & 0.5 \\
\hline Hamedan & 0.52 & 0.64 & 0.49 & 0.38 & 0.61 & 0.46 & 0.74 & 0.49 & 0.98 & 1 & 0.64 & 0.62 & 0.61 & 0.54 & 0.55 & 0.59 \\
\hline Ardabil & 0.33 & 0.38 & 0.41 & 0.41 & 0.71 & 0.55 & 0.94 & 0.64 & 1.03 & 0.44 & 1 & 0.74 & 0.55 & 0.52 & 0.64 & 0.74 \\
\hline Moghan & 0.58 & 0.64 & 0.67 & 0.49 & 0.89 & 0.46 & 0.67 & 0.67 & 0.81 & 0.46 & 0.29 & 1 & 0.47 & 0.5 & 0.49 & 0.59 \\
\hline France & 0.74 & 0.61 & 0.64 & 0.58 & 0.41 & 0.61 & 0.64 & 0.41 & 0.64 & 0.49 & 0.58 & 0.74 & 1 & 0.55 & 0.67 & 0.67 \\
\hline Spain 1 & 0.74 & 0.74 & 0.71 & 0.71 & 0.71 & 0.67 & 0.64 & 0.46 & 0.78 & 0.61 & 0.64 & 0.67 & 0.58 & 1 & 0.67 & 0.61 \\
\hline Spain 2 & 0.52 & 0.46 & 0.49 & 0.61 & 0.38 & 0.58 & 0.74 & 0.49 & 0.74 & 0.58 & 0.44 & 0.71 & 0.38 & 0.38 & 1 & 0.76 \\
\hline Spain 3 & 0.52 & 0.46 & 0.61 & 0.49 & 0.49 & 0.46 & 0.67 & 0.49 & 0.67 & 0.52 & 0.29 & 0.52 & 0.38 & 0.49 & 0.27 & 1 \\
\hline
\end{tabular}


B)

\begin{tabular}{|c|c|c|c|c|c|c|c|c|c|c|c|c|c|c|c|c|c|}
\hline C. album & Rudsar & Rasht & $\begin{array}{l}\text { Boyer- } \\
\text { Ahmad } \\
\end{array}$ & Rudan & Moghan & Kivi & Ardabil & Yazdabad & $\begin{array}{l}\text { Shahr- } \\
\text { e-Ray }\end{array}$ & Tehran & Dehloran & Hamadan & Mashhad & Spain 1 & Spain 2 & $\begin{array}{c}\text { France } \\
1 \\
\end{array}$ & $\begin{array}{c}\text { France } \\
2 \\
\end{array}$ \\
\hline Rudsar & $\overline{1}$ & 0.75 & 0.53 & 0.63 & 0.51 & 0.59 & 0.48 & 0.53 & 0.55 & 0.59 & 0.57 & 0.57 & 0.57 & 0.57 & 0.61 & 0.67 & 0.63 \\
\hline Rasht & 0.28 & 1 & 0.61 & 0.67 & 0.51 & 0.55 & 0.48 & 0.57 & 0.55 & 0.63 & 0.65 & 0.61 & 0.65 & 0.69 & 0.77 & 0.79 & 0.63 \\
\hline Boyer-Ahmad & 0.63 & 0.49 & 1 & 0.85 & 0.65 & 0.65 & 0.59 & 0.75 & 0.65 & 0.77 & 0.79 & 0.79 & 0.75 & 0.67 & 0.71 & 0.69 & 0.65 \\
\hline Rudan & 0.45 & 0.39 & 0.15 & 1 & 0.63 & 0.67 & 0.53 & 0.65 & 0.59 & 0.79 & 0.73 & 0.77 & 0.65 & 0.61 & 0.69 & 0.63 & 0.55 \\
\hline Moghan & 0.67 & 0.67 & 0.42 & 0.45 & 1 & 0.59 & 0.85 & 0.77 & 0.75 & 0.55 & 0.53 & 0.53 & 0.61 & 0.61 & 0.61 & 0.59 & 0.75 \\
\hline Kivi & 0.52 & 0.59 & 0.42 & 0.39 & 0.52 & 1 & 0.61 & 0.53 & 0.55 & 0.75 & 0.69 & 0.69 & 0.65 & 0.65 & 0.61 & 0.67 & 0.55 \\
\hline Ardabil & 0.71 & 0.71 & 0.52 & 0.63 & 0.15 & 0.49 & 1 & 0.79 & 0.77 & 0.57 & 0.55 & 0.55 & 0.63 & 0.71 & 0.63 & 0.61 & 0.77 \\
\hline Yazdabad & 0.63 & 0.55 & 0.28 & 0.42 & 0.25 & 0.63 & 0.22 & 1 & 0.89 & 0.61 & 0.63 & 0.63 & 0.83 & 0.79 & 0.79 & 0.73 & 0.85 \\
\hline Shahr-e-Ray & 0.59 & 0.59 & 0.42 & 0.52 & 0.28 & 0.59 & 0.25 & 0.107 & 1 & 0.67 & 0.57 & 0.57 & 0.81 & 0.73 & 0.77 & 0.71 & 0.83 \\
\hline Tehran & 0.52 & 0.45 & 0.25 & 0.22 & 0.59 & 0.28 & 0.55 & 0.49 & 0.39 & 1 & 0.81 & 0.85 & 0.69 & 0.69 & 0.65 & 0.67 & 0.55 \\
\hline Dehloran & 0.55 & 0.42 & 0.22 & 0.3 & 0.63 & 0.36 & 0.59 & 0.45 & 0.55 & 0.2 & 1 & 0.91 & 0.75 & 0.83 & 0.67 & 0.73 & 0.61 \\
\hline Hamadan & 0.55 & 0.49 & 0.22 & 0.25 & 0.63 & 0.36 & 0.59 & 0.45 & 0.55 & 0.15 & 0.08 & 1 & 0.71 & 0.75 & 0.63 & 0.69 & 0.53 \\
\hline Mashhad & 0.55 & 0.42 & 0.28 & 0.42 & 0.49 & 0.42 & 0.45 & 0.17 & 0.2 & 0.36 & 0.28 & 0.33 & 1 & 0.83 & 0.87 & 0.81 & 0.77 \\
\hline Spain 1 & 0.55 & 0.36 & 0.39 & 0.49 & 0.49 & 0.42 & 0.33 & 0.22 & 0.3 & 0.36 & 0.17 & 0.28 & 0.17 & 1 & 0.79 & 0.85 & 0.77 \\
\hline Spain 2 & 0.49 & 0.25 & 0.33 & 0.36 & 0.49 & 0.49 & 0.45 & 0.22 & 0.25 & 0.42 & 0.39 & 0.45 & 0.13 & 0.22 & 1 & 0.85 & 0.77 \\
\hline France 1 & 0.39 & 0.22 & 0.36 & 0.45 & 0.52 & 0.39 & 0.49 & 0.3 & 0.33 & 0.39 & 0.3 & 0.36 & 0.2 & 0.15 & 0.15 & 1 & 0.83 \\
\hline France 2 & 0.45 & 0.45 & 0.42 & 0.59 & 0.28 & 0.59 & 0.25 & 0.15 & 0.17 & 0.59 & 0.49 & 0.63 & 0.25 & 0.25 & 0.25 & 0.17 & 1 \\
\hline
\end{tabular}


Table 5. Analysis of Molecular Variance (AMOVA) for Amaranthus retroflexus (A) and Chenopodium album (B) populations

A)

\begin{tabular}{ccccc}
\hline Source & df & SS & MS & PhiPT \\
\hline Among populations & 1 & 35.967 & 35.967 & $0.21^{* *}$ \\
Within populations & 14 & 160.095 & 11.435 & - \\
Total & 15 & 196.063 & - & - \\
\hline
\end{tabular}

B)

\begin{tabular}{ccccc}
\hline Source & df & SS & MS & PhiPT \\
\hline Among populations & 1 & 27.769 & 27.769 & $0.31^{* *}$ \\
Within populations & 15 & 98.467 & 6.564 & - \\
Total & 16 & 126.235 & - & - \\
\hline
\end{tabular}


A)

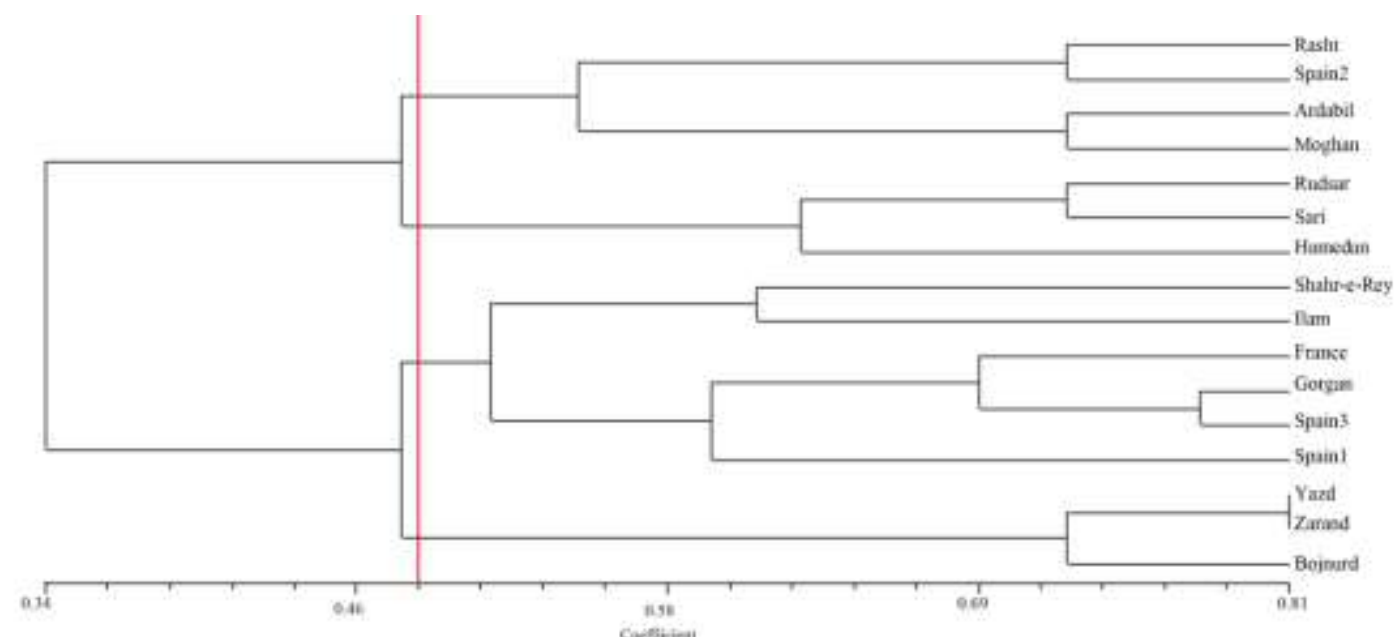

B)

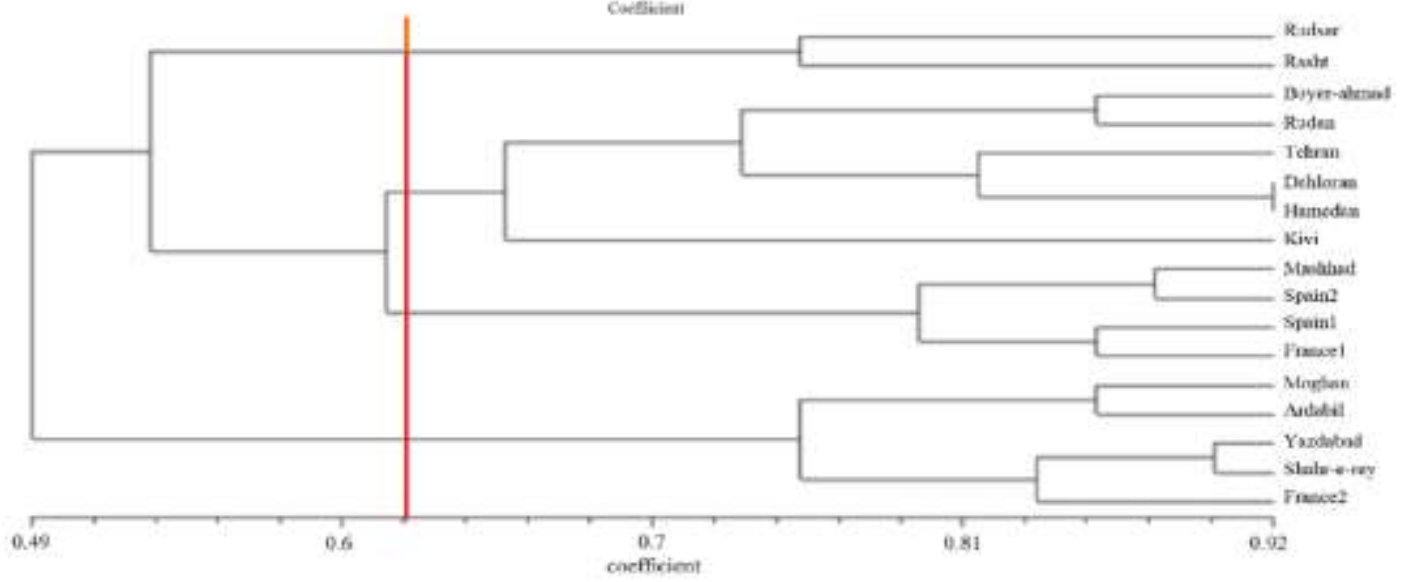

Figure 1. UPGMA clustering of Amaranthus retroflexus (A) and Chenopodium album (B) populations based on Jaccard similarity coefficient calculated from ISSR markers 

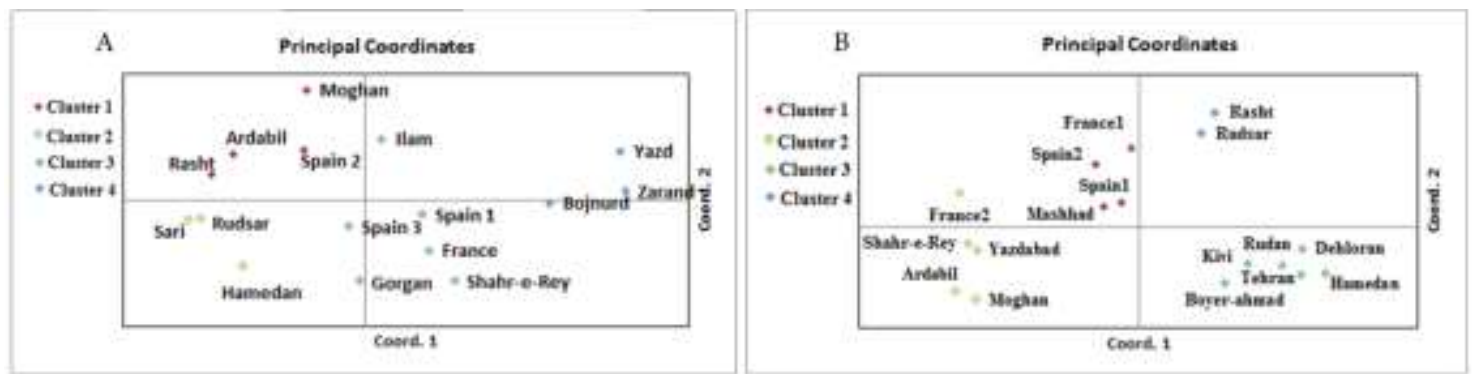

Figure 2. Principal coordinates analysis of 16 Amaranthus retroflexus (A) and 17 Chenopodium album (B) populations based on the genetic variation revealed by ISSR. 
Figures

A)

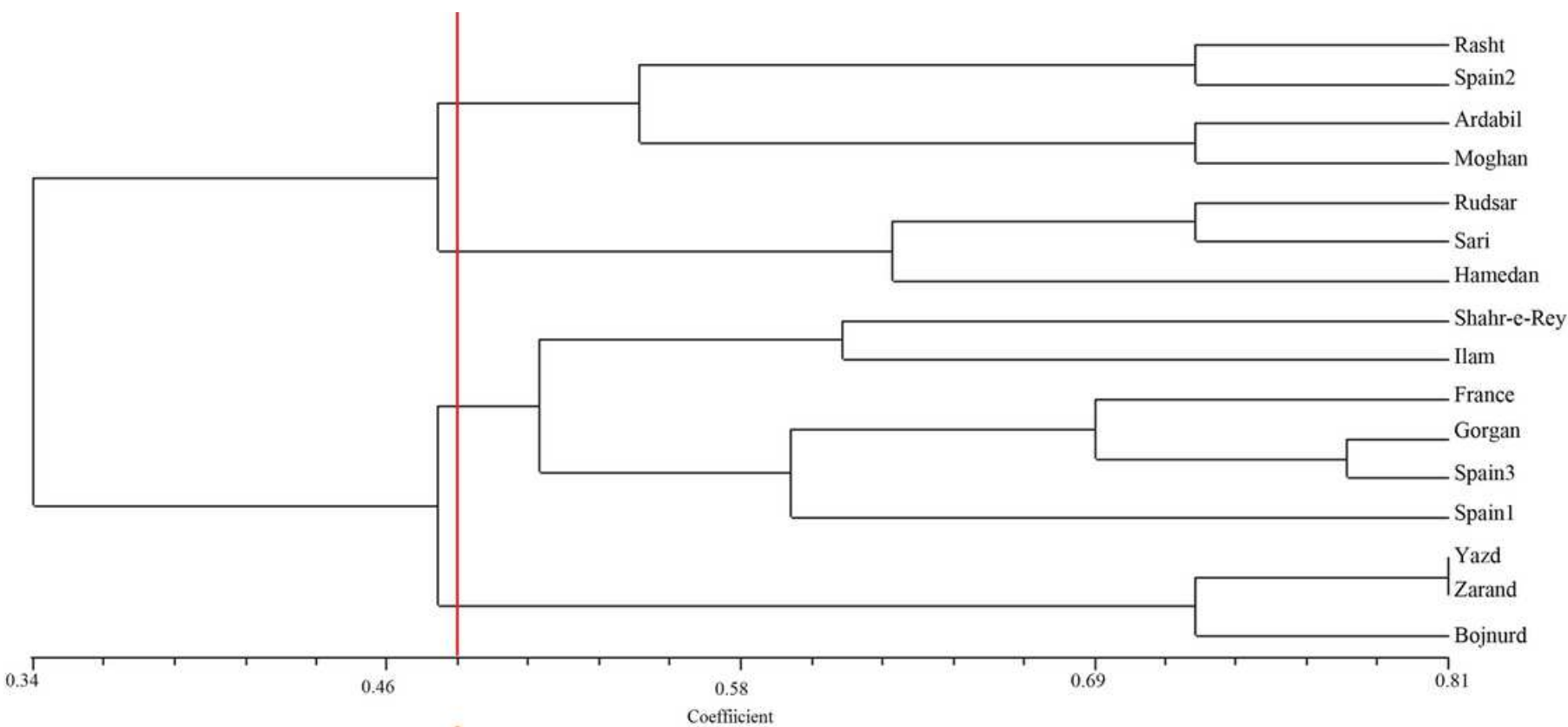

B)

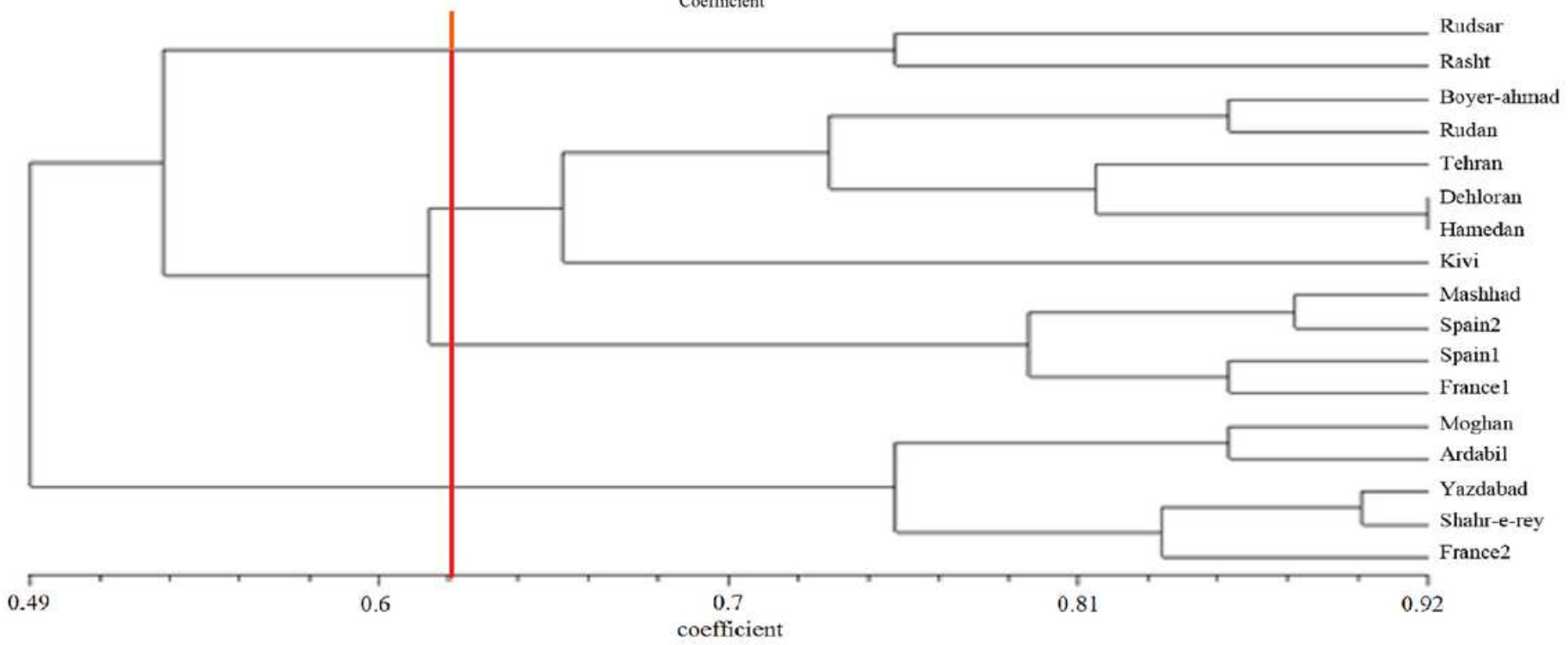

Figure 1

UPGMA clustering of Amaranthus retroflexus (A) and Chenopodium album (B) populations based on Jaccard similarity coefficient calculated from ISSR markers 


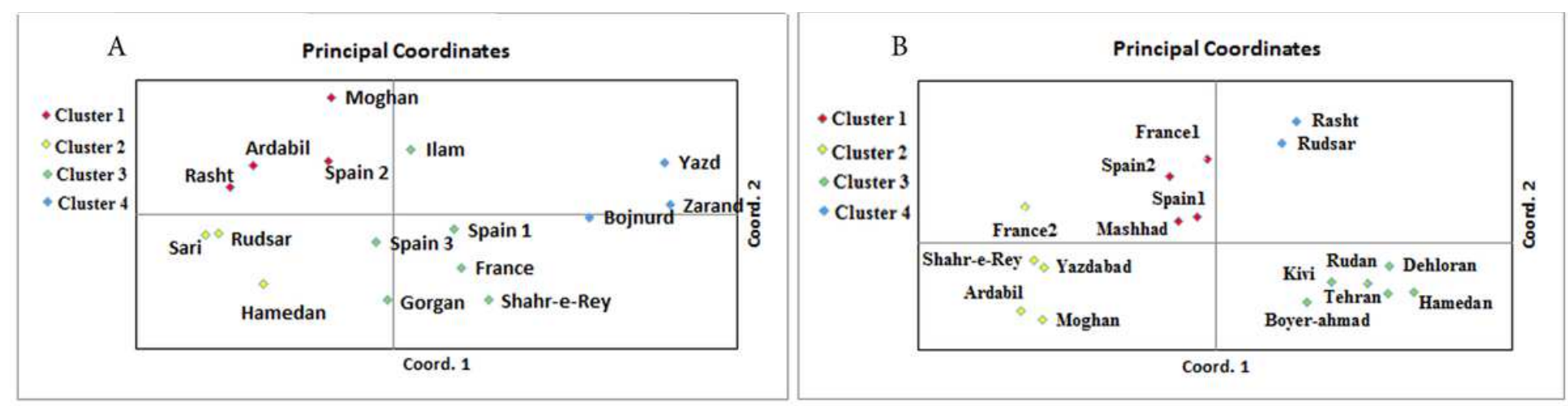

\section{Figure 2}

Principal coordinates analysis of 16 Amaranthus retroflexus (A) and 17 Chenopodium album (B) populations based on the genetic variation revealed by ISSR.

\section{Supplementary Files}

This is a list of supplementary files associated with this preprint. Click to download.

- SupplementalFigure.jpg 